Jpn. J. Oral Bioi., 23 : 677-684, 1981.

\title{
ラット咬筋の組織形成機構の組織化学的研究
}

\author{
桂茂石塚寛 \\ 松本林中江良子 \\ 徳島大学歯学部口腔解剖学第 1 講座 (主任 : 桂 茂教授)
}

〔受付 : 昭和 56 年 9 月 4 日]

\section{Histochemical studies on the histogenesis of rat masseter muscle}

\author{
Shigeru Katsura, Hiroshi Ishizuka, Hayashi Matsumoto \\ and Yoshiko Nakae \\ Department of Oral Anatomy, School of Dentistry, Tokushima University, \\ Kuramoto-cho 3-18-15, Tokushima 770 \\ (Chief : Prof. Shigeru Katsura)
}

[Accepted for publication September 4, 1981]

Key words : masseter / rat / histogenesis / SDH / histochemistry

\begin{abstract}
The cellular differentiation and histogenesis of the architecture of rat masseter were studied by histochemical staining for succinic dehydrogenase (SDH). From day 19 of gestation to day 16 after birth, development of two distinct muscle fibers could be distinguished : fibers with fine formazan diffusely distributed in the sarcoplasm (SS) and fibers with large formazan particles diffusely distributed in the sarcoplasm (SL). After day 16 some muscle fibers showed marked progress in cellular differentiation and became similar to adult fiber types. After day 23 most muscle fibers could be classified into three types. Even after this, cellular differentiation increased progressively and approached that of adult muscle fibers. Until day 1 after birth there were some clusters of muscle fibers. Regions with high and low SL indices were distinguished. Thereafter muscle fibers of both SS and SL types in. creased in number. The SL index of each muscle region increased, especially from day 4 to 16 , although there were regional differences in time of beginning and in the grade of increase. From day 1 to 4 after birth the organization of the primordial muscle structure observed in the cross section became similar to that of an adult muscle and the deepest masseter had the highest SL index. On day 23 after birth the distribution patterns of OI and SI in the cross section became similar to those in adult muscle. The average OI and SI of the muscle regions decreased in the following order : the deepest masseter $>$ superficial masseter $>$ deep masseter. Moreover, the range of the SL index, OI and SI values the primary fasciculi in each region showed significant changes during postnatal development.
\end{abstract}

\section{緒言}

骨格筋線維における myosin ATPase や SDH の発生に伴なう出現状態については詳細に検討さ れ, 発生に伴なって活性の強い線維の数が減少す

徳島市蔵本町 3-18-15（广 770）
る筋と，増加する筋とがあることが指摘されてい る1-9)。これに反して, 咀嚼筋の発生に伴なら筋 組織の細胞構築の変化についての研究は意外に少 なく,ラットの咬筋においては,わずかに Hiraiwa $(1978)^{10)}$, 前田ら $(1978)^{11}$ 等が発生に伴なう筋線 維の分化をコハク酸脱水素酵素 (SDH) 染色法に 
よって研究している報告があげられるのに過ぎな い。しかしながら，氏らの研究は咬筋を構成して いる筋束の如何や同一筋束内での 1 次筋束間の差 異については検討していない。筆者ら ${ }^{12) 13}$ は，さ きに成熟ラット咬筇の細胞構築状態を SDH によ る組織化学的方法によって検討して, 各種筋線維 の出現状態が筋の部位 (起始, 筋腹, 停止) や構成 筋束の如何及び同一筋束内での 1 次筋束によって もかなりの差があることを指摘した。本報では， $\mathrm{SDH}$ 染色法を使用して, ラットの咬笳内におけ る各種筋線維の細胞分化や細胞構築の進行状態を 胎生期から出産後の発生過程を通じて追究した。

\section{実験材料とその方法}

実験試料にはウイスター系のラットを使用し た。胎令の決定は, 腟垢に精子の存在を認めた日 を妊娠第 1 日と見なした。又, 出産後の日数は出 産日を第 1 日とした。胎生18一-22日の胎仔と出産 後 1-40日のものについて検討した。この際, 胎 生期から出産後25日までのものでは性別を問わず 観察したが, その後のものはすべて雄個体を使用 した。胎生期のものと出産後 4 日までのものとは 咬筋を骨に付着させたままで固定したが，その後 のものは筋を骨からはずした後に固定した。採取 した咬筋を予め液体窒素で冷却したイソペンタン 液中に投入して，30分以上放置した後に，クリオ スタットで $\left(-20^{\circ} \mathrm{C}\right), 10 \mu$ の切片を作製し, 空気 中でスライドグラスに貼布した後に染色を行っ た。SDH 染色は Nachlas ら (1957) ${ }^{14)}$ の方法に 従った。又, 他面, ヘマトキシリン一エオシン染 色を併用して組織像を比較した。 SDH 染色を施 すと, 胎生期から出産後 15 日までのものでは, 殆んどの筋線維内のフォルマザン結晶は筋形質内 にびまん性に出現した。その内, 線維内に太い多 数のフォルマザン結晶が認められる線維 (SL と 略記）と微細なフォルマザン結晶のみられるもの (SS) との 2 種類のものに大別できた (Fig. 3)。 しかしながら, 出産後16日以降からは成体での所 見と同様に, フォルマザン結晶が筋形質膜の直下 に密集し，筋形質内にも太いフォルマザン結晶が みられる小形の細胞 $[S($ 册) ] と, 比較的大形の 細胞で, 微細な結晶が網状にみられる明るい線維
[S(+)]及びその中間で少数のフォルマザン結 晶が筋形質膜の直下に見られ，筋形質内にも中 等度の太さのフォルマザン結晶が見られるもの [S(H)]の 3 種類の筋線維が識別されるようにな り，その後ではその数を漸増して，23日以降では 大部分の筋線維が $\mathrm{S}(\mathrm{H}), \mathrm{S}(+), \mathrm{S}(+)$ 形へと 分化してきた (Fig. 3)。従って, 生後16日までの ものでは oxidative index のかわりに SL index= [(SL/whole fibers $) \times 100]$ 值を, 又, 23日以降 のものでは oxidative index (OI) (Botterman ら 1978) ${ }^{15)}$ と $\mathrm{S}$ index (SI) (Katsura ら1980;

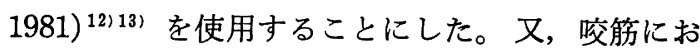
けるこれらの值は筋の部位によって差異があるこ とが知られたので (Katsura ら1980) ${ }^{12) 13)}$, 今回の 実験では比較的部位差の少ない筋腹部で, しかも 比較的類似した横断像を示す部位を選んで比較検 討することにした。

\section{実 験成績}

\section{1. 胎生期の所見}

胎生期の咬筋の組織は未分化で，遊離した筋系 の細胞が大部分であったが, 所々では数ケの筋系 の細胞が集合している場所も見出された(Fig. 3)。 これらの細胞はへマトキシリンーエオシン染色に よると筋管細胞が大部分であったが，それ以外に 筋原細胞もかなり多数存在していた。又, それら 以外の結合織内の細胞も見出された。しかしなが ら, SDH 染色を行うと筋系の 細胞以外のもので は著明なフォルマザン結晶の出現が見られなかっ たので, 笳系の細胞とその他の細胞との識別は容 易であった。又，筋管細胞のなかでも未分化なも のではフォルマザン結晶の出現の少ないものが存 在した。従って, 本実験では明らかにフォルマザ ン結晶が見出されるまでに分化を進めている筋管 細胞や筋線維についてのみ測定することにした。

この期の䇗管細胞の大部分のものは SS 型であ ったが，SL 細胞もすでに少数ながら混在してい た(Fig. 3)。しかし胎生19日になると SS および SL 細胞はともに増数するとともに増大し, フォ ルマザン結晶も増加してきた。又, SL index に は高值を示す場所と低值を示す場所とが識別され た(Fig. 1)。さらに, 胎生 22 日になると, 成熟個 

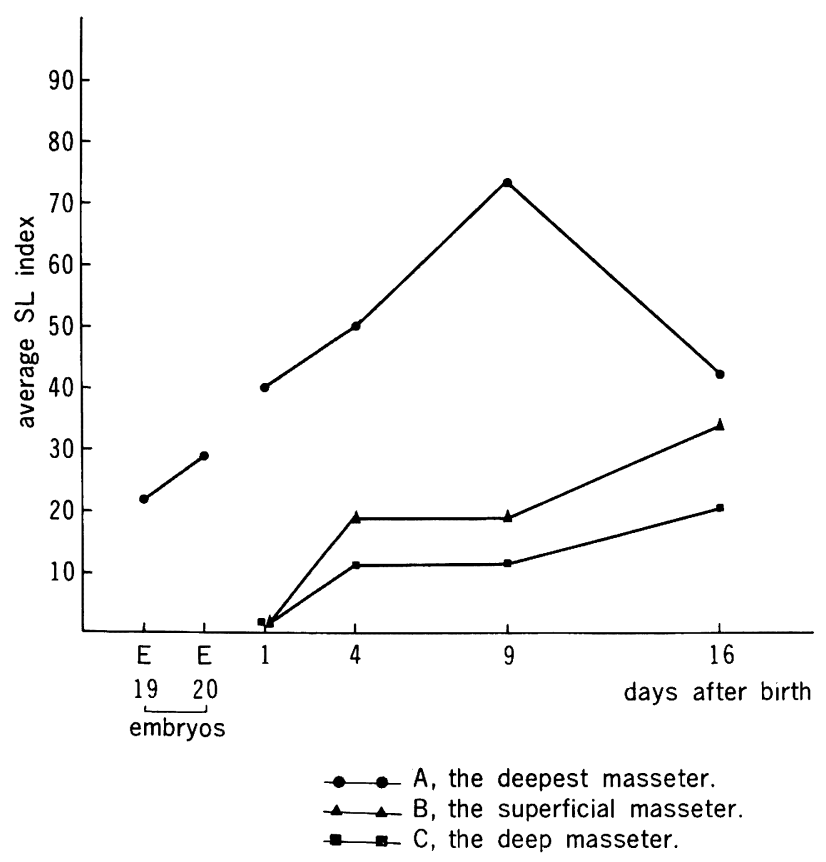

Fig. 1 Changes in the average SL index values in different regions of rat masseter muscle during postnatal development.

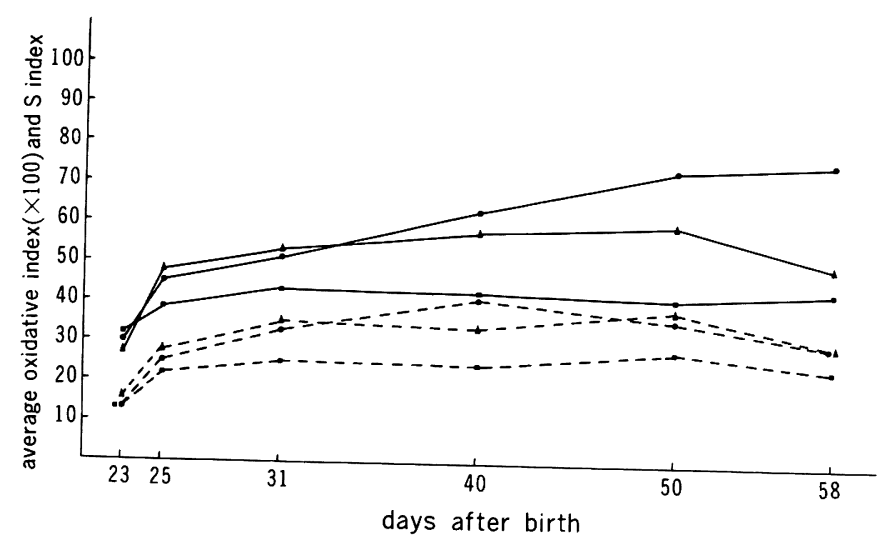

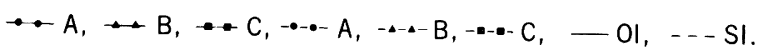

Fig. 2 Changes in the average oxidative index (OI) and $\mathrm{S}$ index (SI) values in different regions of rat masseter during postnatal development

体で見出された浅層筋，深層筋，最深層筋の原基 と考えられる筋束が識別できるようになった。こ の期のものでは 1 次筋束の形成は未だ行なわれて いなかったが，成熟個体と同様に，最深層筋の原 基に一致する部分では SL index が最も高く，浅 層筋や哚層筋の原基の部分では著しく低值を示し
ていた。

2 . 出産後の所見

1）第 1 日目の所見

最深層筋原基の部分では筋組織の 分化がお お く,大部分の筋系の細胞は単離していたが，この部 分の SL index は最も高かった(40)。これに反し 


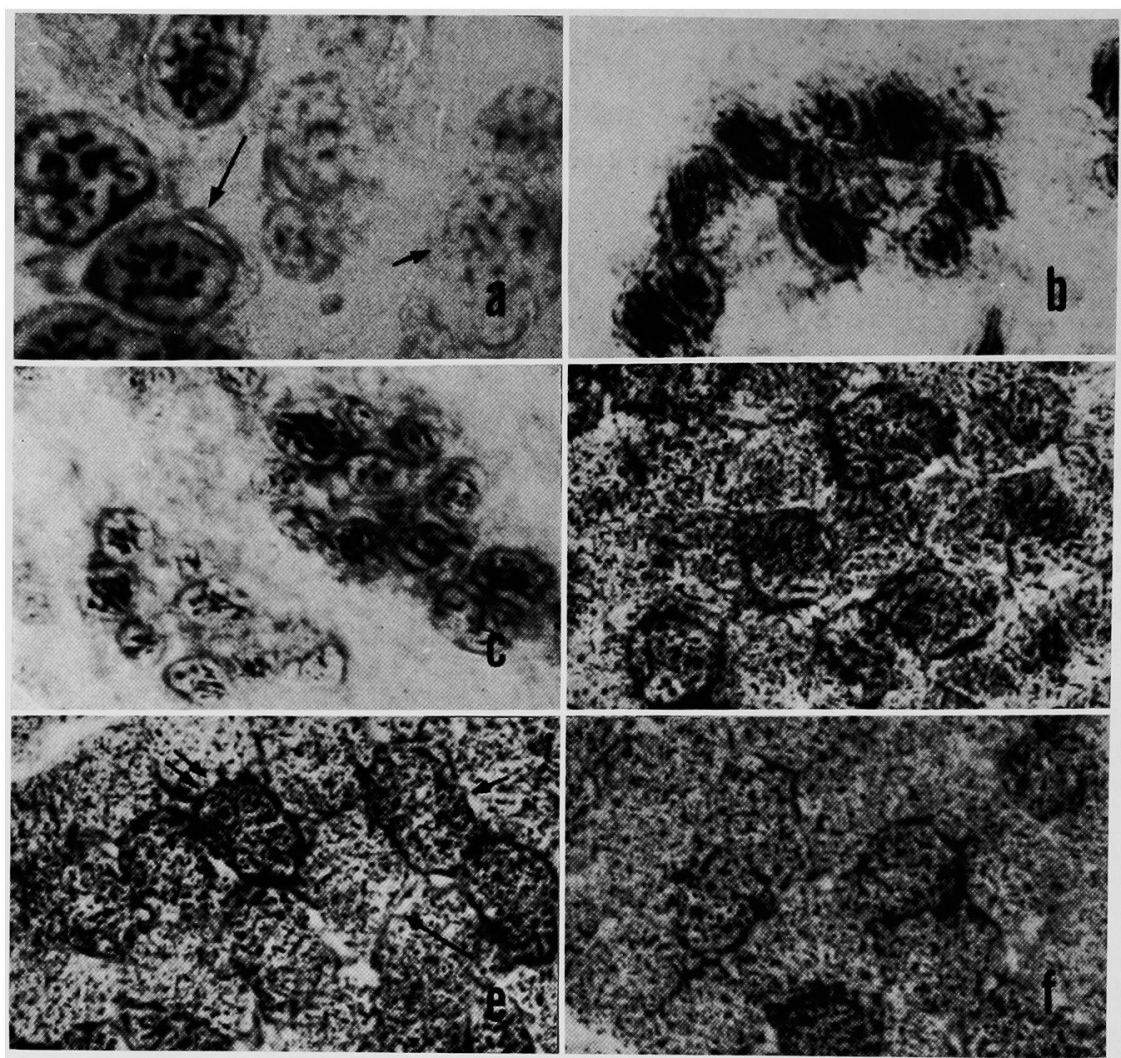

Fig. 3 Photomicrographs showing progress of cellular differentiation stained with SDH. a-d: showing two muscle fiber types: SL $(\nearrow$ ) and $\operatorname{SS}(\nearrow)$. a : on day 1 after birth. $\times 900, \mathrm{~b}:$ on day 4 after birth, region A. $\times 450, \mathrm{c}:$ on day 4 after birth, region $B . \times 450, d$ : on day $6 . \times 450$. e- $f$ : showing transition of muscle fibers from SS and SL types to $\mathrm{S}(\mathrm{H}), \mathrm{S}(H)$ and $\mathrm{S}(+)$ types (adult types). $\mathrm{e}:$ on day 23 after birth, region $\mathrm{A} . \times 450, \mathrm{f}:$ on day 23 after birth, region $\mathrm{B} . \times 450$, $\mathrm{S}(\mathrm{H}):(\nearrow \nearrow), \mathrm{S}(\mathrm{H}):(\nearrow), \mathrm{S}(+):(\nearrow)$.

て，浅層筋や深層筋の原基の部分では筋系の細胞 が集団を形成し，網目状に配列して,不完全ながら 1 次筋束を構成している場所も見出された。この 部分における管管細胞や筋線維の大部分は SS 型 で，SL 細胞は少数散在するのに過ぎず，SL in$\operatorname{dex}$ も低值 $(5)$ を示すものが少数の筋束で見られ るのに過ぎなかった(Fig. 1，4）。

2）第 2 日一 23 日までの所見

第 2 日以降では SS, SL 細胞ともに増数, 増大 して, 内筋周膜を構成する結合織の分化も著明に なり, 漸次 1 次筋束, 2 次筋束の区域も明膫にな り,成体組織に類似してきた。しかしながら,この 間においても最深層筋の組織形成は最も遅れてい た。又, 浅層筋や深層筋内でも, SL 細胞が増数し
てきたが，これらのものは筋束の周辺部で増数を 示すものが多かった。又，4-9日のものでは最 深層筋内の SL は著し、増加を示し, 他の部との 差異が増大するばかりでなく，浅層筋と深層筋内 での SL index の差も著明になってきた。しかし ながら，その後から16日へかけて浅層筋，樑層筋 内における SL index はともに増加を示し，筋束 間の差は少なくなってきた (Fig. 1)。又，各筋束 内での 1 次筋束間の SL index の差は生後 1 日で は少なかったが, 4-9 日の間では大きくなり, 16 日になると再び減少してきた(Fig. 4)。又，16日以 降の筋線維内ではフォルマザン結晶が筋形質膜の 直下へ移動を示す筋線維の数が漸増するようにな り，既述のような成体型に類似してきた(Fig. 3)。 

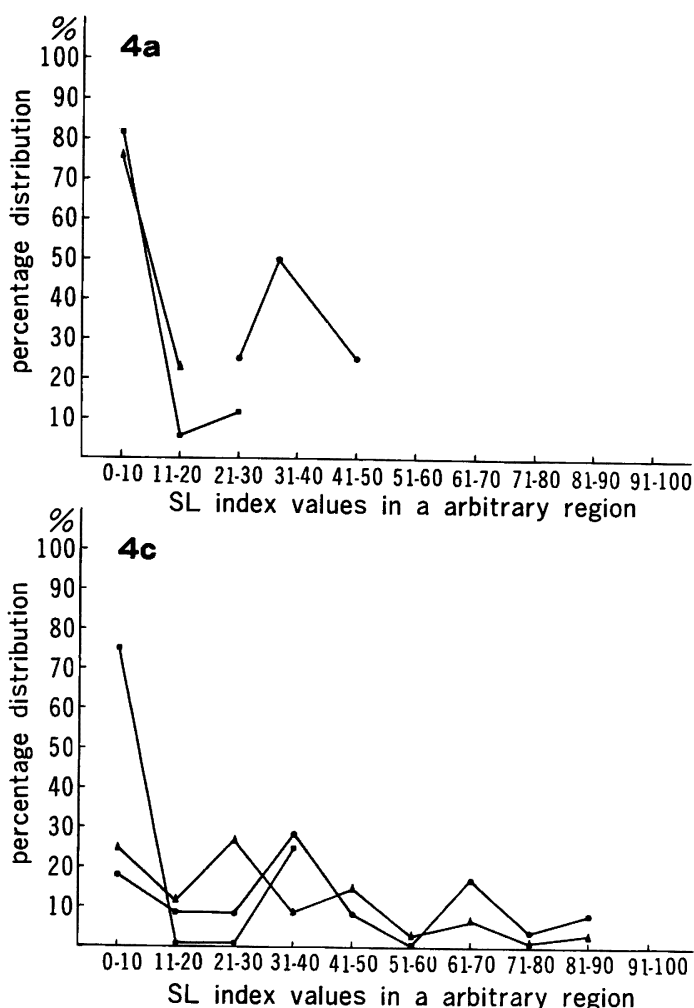
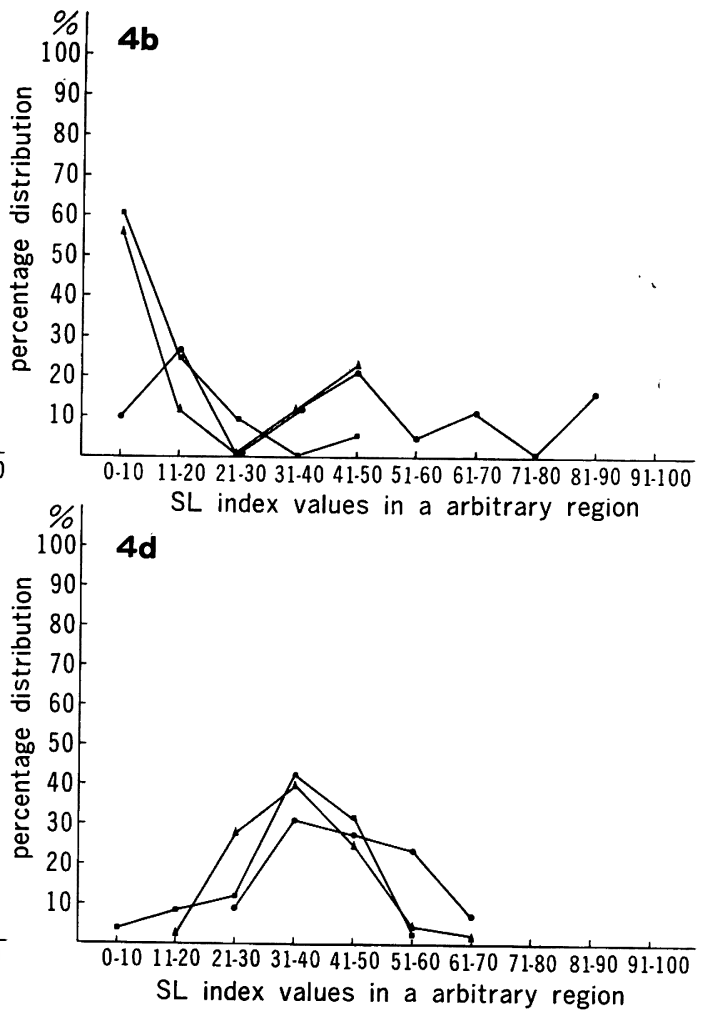

$\rightarrow A, \leadsto B, \ldots$ C. a:1 day after birth, b:4 days after birth, c:9 days after birth, d:16 days after birth.

Fig. 4 Percentage distribution of arbitrary primary fasciculli with different SL index values during postnatal development.

\section{3. 第23日以降の所見}

既述のように，生後23日以降の筋線維では $\mathrm{S}$ (卅), S (\#), S (+) 線維の識別が可能になった が(Fig. 3)，23-40日の間のものでは，S(H)で ありながら他の細胞よりは小形でないものや, 又, 筋形質膜直下のフォルマザンの密集度の低いもの

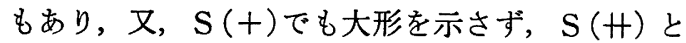
の中間型を示すものがあり， $\mathrm{S}(\mathrm{H})$ と $\mathrm{S}(\mathrm{H}), \mathrm{S}$ (H) と $\mathrm{S}(+)$ との識別が困難な線維がかなりの頻 度で見出された。OI は各期を通じて最深層筋で は最も高值を示し, 浅層筋がこれにつぎ, 深層筋で は最も低值を示した (Fig. 2)。これに反して, SI は最哚層筋と浅層筋での差は少なく，樑層筋だけ が低值を示していた。又, 各筋束ともに25日以降に おける SI の変動は OI より少なかった(Fig. 2)。 又, 各筋束内における 1 次筋束単位の OI や SI を みると (Fig. 5), 高值を示す筋束の出現率が増加
したが，この傾向は最深層筋で最も著明で，浅層 筋がこれにつぎ，樑層筋では最も低かった。又， 各筋束内での 1 次筋束間の OI や SI の分散範囲 も漸次狭くなってきた(Fig. 5)。さらに40日以降 では筋線維の分化も進み， $\mathrm{S}($ 卅) も小形化し， $\mathrm{S}$ （+）も大形化するとともに淡染性になり， $\mathrm{S}($ 卅), $\mathrm{S}(H) ， \mathrm{~S}(+)$ の識別は容易になってきた。

\section{考察}

筆者ら ${ }^{12131}$ はさきにラットの咬筋の深層筋内に $\mathrm{SDH}$ 活性の高い1 次筋束が集合している筋束が 存在することを見出し， 最深層笳と命名した ${ }^{12)}$ 。 又, 成熟個体では咬筋を構成している筋束のなか でも, OI や SI 等の平均值は最深層筋で最も高 く，浅層筋がこれにつぎ，深層筇では最低值を示 すことも指摘した。本実験成績からすると，これ らの組織化学的にみられる細胞構築パターンは胎 

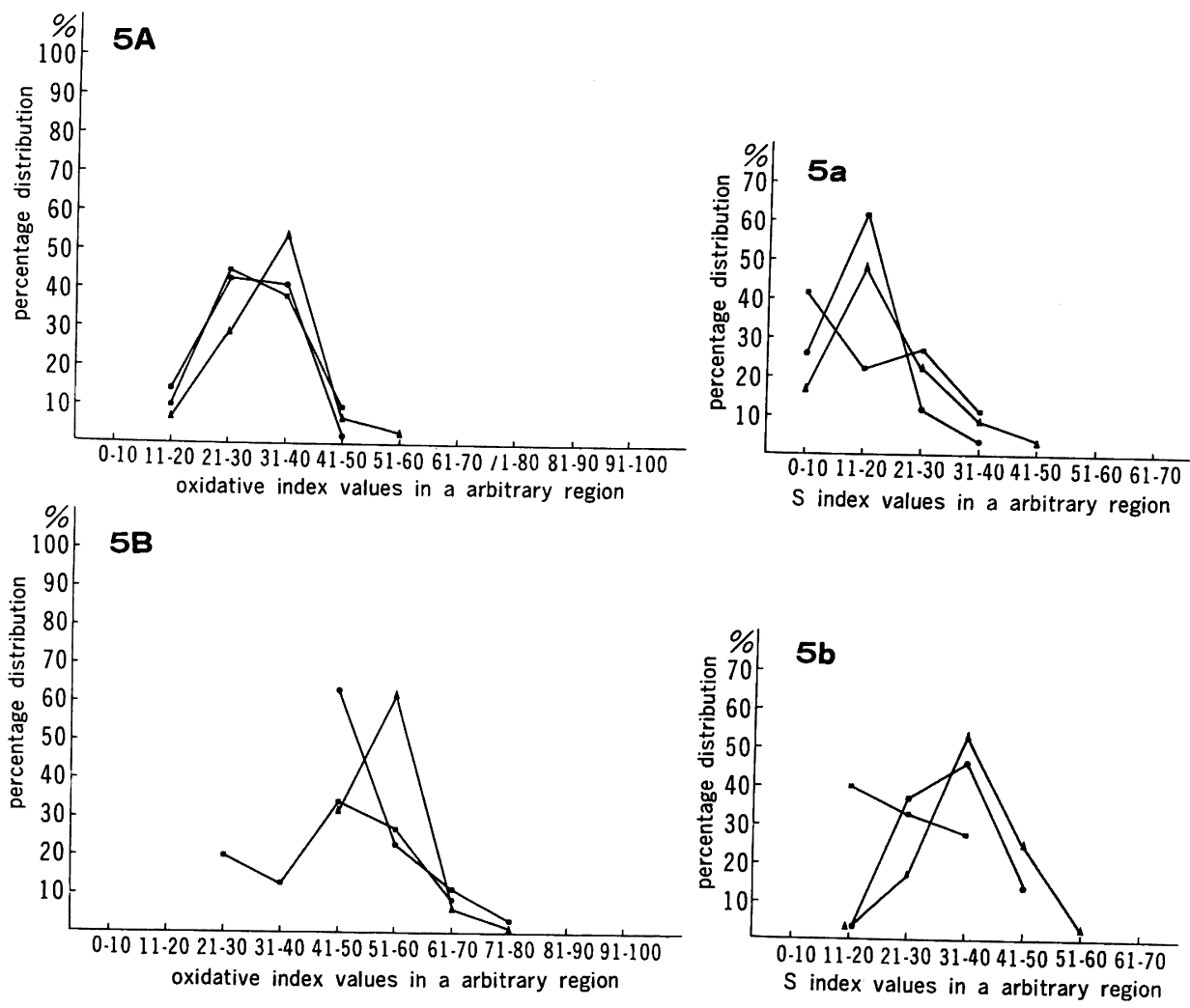

$\rightarrow A, \leftrightarrow B, \rightarrow$ C. A-C:Ol, a-c:SI. A-a:23 days after birth, B-b:31 days after birth.

Fig. 5 Percentage distribution of arbitrary primary fasciculli with different OI and SI values during postnatal development.

生22日からすでに成熟個体での最深層筋の原基に 一致して SL index の高、䈘束が分化しており, 出産後 4 日になると SL index の最深層筋, 浅層 筋, 樑層筋の各筋束間の差が成熟個体と同様に出 現することを見出した。しかしながら，このよう な筋束間に差の出現する機構は不明である。次に 筋線維の形態分化をみると，いずれの筋束の原基 においても胎生期においては SS 型の細胞が大部 分であったが, 生後の日数の増加に伴って SS 及 び SL 細胞ともに増数し，骨膜や腱表面における 筋線維の新造も加わって SL index は増加してき た。この際, SL index の増加速度には筋束間で 差がみられ，最深層筋では最も早かった。又，16 日以降からは筋形質内でのフォルマザンの分布状 態に変化が見え始め, 特に筋形質膜直下へのフォ ルマザンの集合の見られる筋線維が漸増し， S (H), S (H), S (十) に識別できる線維の数が増
加してきた。この分化速度む又, 最深層筋では最 も早く, 浅層筋がこれについでいた。さらに，23 日になると大部分の筋線維は成体型になった。従 って, 筇線維の分化の進行は, まず SS, SL 型に なり, ついで成体型の $\mathrm{S}(\mathrm{H}), \mathrm{S}(+), \mathrm{S}(+)$ 人 と分化を進めるものと思われる。この際, SS か ら $\mathrm{SL}$, 又, $\mathrm{SS}$ から $\mathrm{S}(+)$ 或は $\mathrm{S}(H) へ, \mathrm{SL}$ から $\mathrm{S}(\mathrm{H})$ 或は $\mathrm{S}(H)$ 一の転換の可能性が推測さ れるが，それらの転換機構は不明である。筆者ら は SS と SL 細胞との融合を推測させるような像 を認めているので, 細胞融合による転換の可能性 も否定できないように思われる。又, SL index の増加の一部には新生される筋線維に SL 型の細 胞が多いことも無視できないように思われる。Hiraiwa $(1978)^{10)}$ はラットの咬筋の発生に伴う形態 分化を $\mathrm{SDH}$ 染色で観察して, 胎生期から生後 5 一10日の間ではフォルマザンの出現状態には筋細 
胞間に差異はみとめられず，5-10日後から小数の dense granule を持つものと持たないものとが区 別されるようになり，11一20日になると濃染す るものと淡染するものとの 2 種類のものが見られ るようになり，30日後では成体と同様に濃染 $(\mathrm{red})$ と淡染 (white) 性の 2 種の筋線維から構成される ようになり，中間型を欠くことを報告している。 又, 前田ら $(1978)^{11)}$ はラット (SD 系) の咬筋の 浅層部の発生に伴う筋線維の分化を同じく $\mathrm{SDH}$ 染色で追究して, 生後10日までのものでは活性が 低いものばかりであるが，15日後からは強いもの と弱いものの 2 種類の 線維が識別できるようにな り，15一20日後からは筋形質膜の直下にフォルマ ザンの結晶がみられるものが識別されるようにな り，30日後からは成体型と略々同様に濃染するも のと淡染するものとの 2 種類の線維が見られるよ うになることを報告している。筆者らの本実験所 見は，氏らの所見と一部では軌を一にしていたが， 筆者らが胎生期からすでに SS と SL 型の細胞が 見られることを指摘している点や，16一23日と比 較的早期から成体型の筋線維へ分化することを指 摘している点ではやや意見を異にしていた。恐ら くは判定規準が主観的に行なわれることによるも のと推測される。又, 筆者らは各筋束間及び同一 筋束内での 1 次筋束間でも筋線維の分化の進展状
態や OI や SI と SL index 值に差があることを 見出したが，この所見は細胞ならびに組織分化が 筋束単位に, 又さらに 1 次筋束単位に調整されて いる可能性を示しているものと思われる。しかし ながら,これらの差の出現機構も又不明である。哺 乳類の骨格筋でも動物の種類や筋の種類によって 異なるが, 発生に伴って myosin ATPase 活性の 強い筋線維が減少するものと，反対に増加するも のとがあることが報告されている。又, $\mathrm{SDH}$ 染 色によっても，最初はすべて濃染性であるが，発 生に伴って淡染性のものが増加するものやその逆

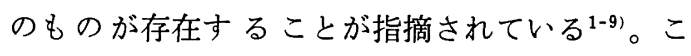
れらの所見が発生に伴って笳線維の種類に転換が 起るとする点では筆者らの所見と軌を一にしてい た。このような転換の起る原因として, 神経支配 の影響が大きいことを指摘する報告や5)16-17)，多 重神経支配から単一神経支配一の転換 ${ }^{18-24)}$ による とする説が報告されているが，これら以外に遺伝 子レベルで既に決定されているのか, 或は生後に 受ける種々な要因によって順次決定されて行くの か等については今後の研究にまたなければならな W。

稿を終えるにあたり，研究の遂行に御尽力をいただい た徳島大学歯学部稲住修次技官に感謝いたします。

抄録 : ラットの咬筋の発生に伴なら筋線維の分化と筋組織の細胞構筑状態の推移を SDH 染色法によって 検討した。生後16日までの筇管細胞や筋線維では 比較的太いフォルマザン結晶が筋形質内にびまん性に存在 する型（SL）と微細なフォルマザン結晶が存在するもの（SS）の2 種類に大別された。その後, 16日以降か らは成体型に移行する線維が漸増し，23日以降では殆んどすべての笳線維が成体型の 3 種の筋線維に分化し てきた。SL index=[SL/(whole fibers) $\times 100]$ は生後 4ー16日の間で著しく増加した。又, 胎生19日から, すでに SL index の高い場所と低い場所とが識別され, 生後1 日でも成体筋でみられたと同様に, 最深層筋 の原基に一致して高いSL index を示す場所が見出された。又, 生後 4 日からは最深層筋で最も高く, 浅層 筋がこれにつぎ，深層筋で最低值を示す成体型の細胞構築パターンが認められた。さらに23日以降になると， OI や SI の横断面上での分布パターンは成体と略々類似してきた。

\section{文献}

1) Close, R.: Dynamic properties of fast and slow skeletal muscles of the rat during development. J. Physiol., 173 : 74-95, 1964.

2) Chiakulas, J. J. and Pauly, J. E.: A study of postnatal growth of skeletal muscle in the rat. Anat. Rec., $152: 55-61,1965$.

3) Brooke, M. H., Williamson, E. and
KAISER K. K. : The behavior of four fiber types in developing and reinnervated muscle. Arch. Neurol. (Chic.), $25: 360-366$, 1971.

4) Kugelberg, E.: Adaptive transformation of rat soleus motor units during growth. Histochemistry and contraction speed. $J$. Neurol. Sci., 27 : 269-289, 1976.

5) Rubinstein, N. A. and Kelly, A. M. : 
Myogenic and neurogenic contributions to the development of fast and slow twitch muscles in rat. Devel. Biol., $62: 473-485$, 1978.

6) Goldspink, G.: Biochemical and physiological changes associated with the postnatal development of the biceps brachii. Comp. Biochem. Physiol., 7 : 157-168, 1962.

7) GoldsPink, G. and WARD, P. S.: Changes in rodent muscle fiber types during postnatal growth, undernutrition and exercise. J. Physiol., 296 : 453-469, 1979.

8) Aquin, L. and N. BAnchero, N.: The cytoarchitecture and capillary supply in the skeletal muscle of growing dogs. J. Anat., 132 : 3, 341-356, 1981.

9) Kelly, A. M. and Rubinstein, N. A. : Why are fetal muscle slow? Nature, 288 : 20, 266-269, 1980.

10) Hiraiw A, T. : Histochemical properties of masticatory muscle of growing rat and of matured mammals. Comp. Biochem. Physiol., $59 \mathrm{~A}:$ : 231-238, 1978.

11) 前田憲彦, 花井 汎：咀嚼器官の生後分化に関 する研究. (1) 咬筋を構成する筋線維の分化. 城歯大紀要, $7(2): 219-222,1978$.

12）桂 茂, 石塚 寛, 松本 林, 中江良子：ラッ 卜咬筋の細胞構築と組織形成. 解剖誌, 55 (4): 486-487, 1980.

13) Katsura, S., Ishizuka, H., Matsumoto, H. and NAKAE, Y.: Histochemical studies on the architecture of rat masseter muscle. (投稿中), 1981 .

14) Nachlas, M., Tsou, M. K., DE SouzA, E., Cheng, C. and Seligman, A. M. : Cytochemical demonstration of succinic dehydrogenase by use of a new p-nitrophenyl substituted ditetrazole. J. Histochem. Cytochem., 5 : 420-436, 1957.

15) Botterman, B. R., Binder, M. D. and STUART, D. G.: Functional anatomy of the association between motor units and muscle receptors. Amer. Zool., 18 : 135-152, 1978.

16) Karpati, G. M. D. and Engel, W. K. M. D. and Bethesda, M. D. : Neural trophic function. A new aspect demonstrated histochemically in developing soleus muscle. Arch. Neurol., 17 : 542-545, 1967.

17) ENGEL, W. K. and KARPATI, G. : Impaired skeletal muscle maturation following neonatal neurectomy. Devel. Biol., 17 : 713-723, 1968.

18) Redfern, P. A.: Neuromuscular transmission in new-born rats. J. Physiol. Lond., 209 : 701-709, 1970.

19) Bagust, J., Lewis, D. M. and WesterMAN, R. A.: Polyneural innervation of kitten skeletal muscle. J. Physiol. 229 : 241255, 1973.

20) Bennett, M. R. and Pettigrew, A. G. : The formation of synapses in striated muscle during development. J. Physiol., 241 : 515-545, 1974.

21) Brown, M. C., JANSEN, J. K. S. and VAN Essen, D.: Polyneuronal innervation of skeletal muscle in new-born rats and its elimination during maturation. J. Physiol., 261 : 387-422, 1976.

22) Riley, D. A.: Spontaneous elimination of nerve terminals from the end-plates of developing skeletal myofibres. Brain Res., 134 : 279-285, 1977.

23) Gauthier, G. F., Lowey, S. and Hobbs, A. W. : Fast and slow myosin in developing muscle fibers. Nature, 274 : 25-29, 1978.

24) Betz, W. J., Caldwell, J. H. and RibCHESTER, R. R. : The size of motor units during post-natal development of rat lumbrical muscle. J. Physiol., 297 : 463-478, 1979 . 